\title{
A METHOD FOR CUTTING AND PREPARING THIN SECTIONS OF FROZEN SOIL
}

\author{
By T. E. Osterkamp \\ (Geophysical Institute, University of Alaska, Fairbanks, Alaska 99701, U.S.A.)
}

\begin{abstract}
A diamond wire saw was modified for cutting thin sections of frozen soil and suitable operating conditions were determined experimentally. It was found that a lubricated wire, $0.34 \mathrm{~mm}$ in diameter, operated at cutting velocities of $100-300 \mathrm{~mm} \mathrm{~s}^{-1}$ and cutting forces $0.02-0.1 \mathrm{~kg}$ produced smooth cut surfaces on thin sections $0.4^{-0.5} \mathrm{~mm}$ in thickness. The temperature and wire size were not critical operating parameters and the wire tensions recommended by the manufacturer were satisfactory. A method of mounting the thin sections is also described.

RÉsumÉ. Une methode pour couper et preparer des sections minces de sol gelé. On a modifié une scie à diamant constituée d'un fil métallique pour couper des sections minces de sol gelé et on a déterminé expérimentalement le mode opératoire convenable. On a trouvé qu'un fil lubrifié de $0,34 \mathrm{~mm}$ de diamètre, travaillant à des vitesses de coupe de 100 à $300 \mathrm{~mm}$ par seconde et à des forces de 0,02 à $0,1 \mathrm{~kg}$, produisait des coupes lisses sur des section minces de 0,4 à $0,5 \mathrm{~mm}$ d'épaisseur. La température et les dimensions du fil ne sont pas des paramètres critiques de mise en oeuvre et les tensions recommandées par le constructeur sont satisfaisantes. On décrit aussi und méthode de montage des sections minces.

Zusammenfassung. Eine Methode zur Erzeugung von Dünnschliffen aus gefrorenem Boden. Eine DiamantDrahtsäge wurde zum Schneiden von Dünnschliffen aus gefrorenem Boden eingerichtet; experimentell wurden geeignete Verfahrensweisen gefunden. Es ergab sich, dass mit einem geölten Draht von o.34 mm Durchmesser eine Schnittgeschwindigkeit von $100-300 \mathrm{~mm}$ pro s zu erreichen war. Mit Schnittkräften von $0,02-0,1 \mathrm{~kg}$ konnten glatte Schnittflächen an Dünnschliffen von $0,4-0,5 \mathrm{~mm}$ Dicke erzeugt werden. Temperatur und Drahtdicke erwiesen sich nicht als kritische Parameter des Verfahrens; die vom Hersteller empfohlene Drahtspannung war korrekt. Es wird auch eine Methode zur Montage der Dünnschliffe angegeben.
\end{abstract}

Frozen ground often contains ice lenses formed when the soil freezes. These lenses cause frost heaving, have a marked effect on the physical and mechanical properties of frozen soil, and modify transport processes in frozen soils (e.g. infiltration of water, moisture migration during freezing and heat transfer). While some effort has been directed toward determining the structure and properties of ice lenses (Penner, I96r ; Kinosita, I966) it has been hampered by the lack of a method for cutting frozen soils into thin sections which are necessary to study the structure of the ice. This paper describes a method for cutting frozen soils into thin sections and for mounting and preserving these thin sections.

A diamond wire saw (Laser Technology, Inc., Model 2006A) was modified to cut thin sections of frozen soil and permafrost. The modifications consisted of using low-temperature lubricants in all moving parts and redesigning the sample support table to accommodate cylindrical frozen soil cores. With this type of wire saw, the sample is mounted on a cutting table, counterbalanced by adjustable weights which allow for variations of the cutting force. Cutting action is provided by a diamond-impregnated wire mounted on idler pulleys and pulled across the sample by a variable speed reversing electric motor. Sections as thin as $0.2 \mathrm{~mm}$ were produced, but these proved to be too fragile to handle conveniently and thicknesses of $0.4^{-0.5} \mathrm{~mm}$ or more were commonly used. The thin sections were cut with the saw mounted in a deep freeze or in a cold room. Operating temperatures ranging from -3 to $-25^{\circ} \mathrm{C}$ were used, but the temperature did not appear to affect the quality of the thin sections.

Wire velocities in the range $100-300 \mathrm{~mm} \mathrm{~s}^{-1}$, and cutting forces of $0.02-0.1 \mathrm{~kg}$, produced smooth-cut surfaces in a reasonable period of time. Greater wire velocities and/or cutting forces produced ragged cut surfaces and smaller ones required very long cutting times. The wire tensions recommended by the manufacturer were satisfactory and wire diameters $0.07^{6}-0.3^{8} \mathrm{~mm}$ were used; however, the fine wires had a tendency to break and the thickest 
wire was stiff and difficult to handle. A wire diameter of $0.34 \mathrm{~mm}$ was found to be a convenient compromise. It was necessary to use a lubricant (Dow Corning 200 fluid) applied at the rate of several drops per minute to the wire to obtain smooth cut surfaces and to inhibit deposition of soil particles on the surfaces of the thin sections.

When a thin section was cut from a core it was placed on an absorbent tissue and the lubricant wiped from it with another tissue although this may not be necessary for some studies. The thin section was then mounted between two projector-slide cover glasses, the edges sealed with tape, and then placed in a plastic bag which was also tightly sealed. Thin sections prepared and mounted in this manner were stored for several months in a deep freeze at $-25^{\circ} \mathrm{C}$ with no apparent deterioration. The thin sections were photographed with ordinary light or polarized light using a $35 \mathrm{~mm}$ SLR camera with a macro lens. Details of the ice crystal structure and three-grain boundaries were determined by placing the thin sections on the cold stage of a low-power binocular microscope which was also fitted with a camera attachment for photographing the thin sections. The results of these studies on the structure of ice lenses in frozen soils and permafrost are presented elsewhere (Osterkamp, I975).

\section{Acknowledgements}

This paper is the result of research sponsored by the Office of Water Resources Research, U.S. Department of the Interior, Project C-4049.

MS. received 3 November 1975 and in revised form II June 1976

\section{REFERENCES}

Kinosita [i.e. Kinoshita], S. ı 966 . Tsuchi-ryūshio pukumu kōri no hakuhen [Thin section of frozen soil]. Teion-kagaku: Low Temperature Science, Ser. A, [No.] 24, p. 311-14.

Osterkamp, T. E. 1975. Structure and properties of ice lenses in frozen ground. College, Alaska, Geophysical Institute, University of Alaska. (UAG R-233. Sea Grant Report No. 75-r.)

Penner, E. 196r. Ice-grain structure and crystal orientation in an ice lens from Leda clay. Geological Society of America. Bulletin, Vol. 72, No. 10, p. 1575-77. 